\title{
Abundance and spatial-temporal distribution of the shrimp Xiphopenaeus kroyeri (Decapoda: Penaeidae): an exploited species in southeast Brazil
}

\author{
E. R. Silva ${ }^{a *}$, G. S. Sancinetti ${ }^{b}$, A. Fransozo ${ }^{b}$, A. Azevedo and R. C. Costa ${ }^{a}$ \\ ${ }^{a}$ Núcleo em Ecologia e Desenvolvimento Sócio-Ambiental de Macaé - NUPEM, Universidade Federal do \\ Rio de Janeiro - UFRJ, Av. Professor Aloísio Teixeira, campus UFRJ-Macaé, CEP 27971-550, Macaé, RJ, Brazil \\ ${ }^{b}$ Núcleo de Estudos em Biologia, Ecologia e Cultivo de Crustáceos - NEBECC, Departamento de Zoologia, Instituto de \\ Biociências, Universidade Estadual Paulista "Júlio de Mesquita Filho" - UNESP, CEP 18618-000, Botucatu, SP, Brazil \\ 'Laboratório de Biologia de Camarões Marinhos e de Água Doce - LABCAM, Departamento de Ciências Biológicas, \\ Faculdade de Ciências, Universidade Estadual Paulista "Júlio de Mesquita Filho" - UNESP, \\ CEP 17033-360, Bauru, SP, Brazil \\ *e-mail: evelynraposo.bio@gmail.com
}

Received: March 24, 2015 - Accepted: June 10, 2015 - Distributed: August 31, 2016

(With 6 figures)

\begin{abstract}
This study evaluated the abundance and spatial-temporal distribution of the shrimp Xiphopenaeus kroyeri in the coastal region of Macaé, state of Rio de Janeiro, southeastern Brazil. Monthly samples were obtained from March 2008 to February 2010 in six stations located in Inner (5, 10 and 15m depth) and Outer (25, 35 and 45m depth) areas. It was used a commercial fishery boat equipped with an otter-trawl net $(3.5 \mathrm{~m}$ mouth width, mesh size $20 \mathrm{~mm}$ and $15 \mathrm{~mm}$ in the cod end). Water samples were taken for determination of temperature and salinity, and sediment samples for determination of texture and organic matter content. A total of 7146 shrimps were sampled. About $95 \%$ of all shrimps were caught in the shallow area, i.e., depths $<20 \mathrm{~m}$. Greatest abundances were recorded in winter and spring. No significant correlation was observed between sediment (phi) and abundance. The distribution of $X$. kroyeri in the studied area was closely related to seasonal cold waterfront of the South Atlantic Central Water (SACW) and temperature was the main factor affecting the species abundance.
\end{abstract}

Keywords: abundance, abiotic factors, Penaeidae, SACW.

\section{Abundância e distribuição espaço-temporal do camarão Xiphopenaeus kroyeri (Decapoda: Penaeidae): uma espécie em explotação no sudeste do Brasil}

\section{Resumo}

Este estudo avaliou a abundância e a distribuição espaço-temporal do camarão Xiphopenaeus kroyeri na área costeira da região de Macaé, estado do Rio de Janeiro no sudeste do Brasil. As coletas foram realizadas mensalmente de março de 2008 a fevereiro de 2010 em seis transectos localizados na área interna (5, 10 e $15 \mathrm{~m}$ profundidade) e na área externa (25,35 e $45 \mathrm{~m}$ profundidade). Foi utilizado um barco de pesca comercial equipado com uma rede de arrasto tipo otter-trawl (3,5m abertura de boca, $20 \mathrm{~mm}$ de malha e $15 \mathrm{~mm}$ de ensacador). Foram obtidas amostras de água para determinação da temperatura e da salinidade e amostras de sedimento para determinação da granulometria e teor de matéria orgânica. Um total estimado de 7146 camarões foi amostrado. Aproximadamente, 95\% de todos os camarões foram capturados "Inner Area", ou seja, profundidades $<20 \mathrm{~m}$. As maiores abundâncias foram registradas no inverno e na primavera. Não houve correlação significativa entre o sedimento (phi) e abundância. De acordo com os resultados deste estudo, a distribuição do X. kroyeri na área de estudo está intimamente ligada à sazonalidade da frente térmica da ACAS e a temperatura é o principal fator que afetou a abundância da espécie.

Palavras-chave: abundância, fatores abióticos, Penaeidae, ACAS.

\section{Introduction}

The shrimp Xiphopenaeus kroyeri iis restrict to the Western Atlantic, from North Carolina (United States) to Santa Catarina (south Brazil) (Holthuis, 1980), although there are records of its occurrence in Virginia (United States)and Rio Grande do Sul (Brazil) (D'Incao et al., 2002). In general, it lives exclusively in the marine environment throughout 
its life cycle, and its greatest abundances are reported in shallow depths $(<30 \mathrm{~m})$ (Boschi, 1963). This specie is an important fishery resource globally (Gillett, 2008) and the second most important fishery resource in southeastern Brazil (Castro et al., 2005). The Southeastern-South Brazilian continental shelf suffers with high levels of extraction by artisanal and industrial fisheries, with main targeted species including the most profitable shrimp species such as the pink shrimp Farfantepenaeus brasiliensis (Latreille, 1817) and F. paulensis (Pérez Farfante, 1967), the white shrimp Litopenaeusschimitti (Burkenroad, 1936) and the Atlantic seabob shrimp Xiphopenaeu skroyeri (Heller, 1862) (Valentini et al., 1991a, b; D'Incao et al., 2002; Branco, 2005; Costa et al., 2005).Due to this intense commercial exploitation, in the last few years there has been a decline in shrimp natural stocks (IBAMA, 2006; Vasconcellos et al., 2007).

Xiphopenaeus kroyeri is classified by the Brazilian government as overfished (Brasil, 2004). Therefore, ecological studies about this species, including fishing grounds, are extremely relevant for proposing adequate conservation and management measures.

Ecological studies concerning crustaceans were conducted in southeastern Brazil (Fransozo et al., 2002; Castro et al., 2005; Costa et al., 2007, 2011; Almeida et al. 2012b; Heckler et al., 2013; Silva, 2013), principally on the coast of São Paulo. However, they are scarce on the coast of Rio de Janeiro, especially on the study region, Santana Archipelago, in Macaé (RJ).

The region studied here is a multiple-use Marine Protect Area. Protect Areas constitute a clearly defined geographical space, recognized, dedicated and managed, through legal or other effective means, to achieve the long-term conservation of nature with associated ecosystem services and cultural values (Dudley, 2008). This new overall IUCN protected area definition supersedes the 1999 Marine Protect Areas (MPAs) definition in marine areas.

The multiple-use MPA of Santana Archipelago is localized in a region with peculiar characteristics due to the dynamics of water masses and upwelling event that provides an increase in the concentration of nutrients in the water and thus increases the primary productivity. Despite the peculiarities, only the studies of Semensato and Di Beneditto (2008) and Sancinetti at al. (2014, 2015) focusing on the reproduction of Artemesia longinaris Spence Bate, 1888 were performed in the region.

The establishment of an effective system of protected areas composes the global strategy for the conservation of biodiversity. The spread of the concept that aquatic protected areas are essential for biodiversity conservation of the oceans and continental waters is increasing, allying itself, in the 90 s, the idea of that are essential to maintaining the fishery yield (Dayton et al. 2000; Hyrenbach et al., 2000; Halpern and Warner, 2002; Gell and Roberts, 2003; Brasil, 2007). Several authors have stated that the establishment of these protected areas is an excellent instrument for recovery threatened or collapsed stocks (Bohnsack, 1998;
Ferreira and Maida, 2001; Lubchenco et al., 2003; Russ and Alcala, 2011; Almeida et al., 2012a).

The aim of this study is to analyze the influence of the depth and abiotic factors (temperature, salinity, texture and organic matter content of sediment) on the abundance and spatial and temporal distribution of $X$. kroyeri in the study region.

\section{Material and Methods}

Samples were obtained monthly from March 2008 to February 2010 in Macaé, state of Rio de Janeiro (22²2'33”' S and $\left.41^{\circ} 46^{\prime} 30^{\prime \prime} \mathrm{W}\right)$, in the Marine Protect Area of Santana Archipelago. According to Castro-Filho et al. (1987), the region of Macaé is influenced by the oceanic currents of Brazil $\left(\mathrm{T}>20^{\circ} \mathrm{C}, \mathrm{S}>36\right)$ and Malvinas $\left(\mathrm{T}<15^{\circ} \mathrm{C}, \mathrm{S}<34\right)$. Due to the confluence of both currents between latitudes $25^{\circ} \mathrm{S}$ and $45^{\circ} \mathrm{S}$ of the Western South Atlantic observed in certain periods of the year, there is the formation of water masses like the South Atlantic Central Water (SACW: $\mathrm{T}<20^{\circ} \mathrm{C}, \mathrm{S}<36.4$ ), accounting for part of the convergence of the subtropical gyre and giving rise to the Cabo Frio upwelling, which extends between latitudes $23^{\circ} \mathrm{S}$ e $29^{\circ} \mathrm{S}$ (Campos et al., 1996, 2000; Silveira et al., 2000; Acha et al., 2004). This upwelling is enhanced by coastal winds and by the break of the continental shelf (approximately $50 \mathrm{~km}$ ) driven by the meandering pattern and eddy of the Current of Brazil (Castro and Miranda, 1998; Campos et al., 2000). The combination of these factors leads to intrusion of cold and nitrate-rich waters from the SACW into the coast (Acha et al., 2004) altering the physical conditions and also enhancing water nutrient concentrations (Valentin, 1984). Consequently, the primary productivity of Brazilian Southeast increases, particularly in Cabo Frio, Rio de Janeiro State $\left(23^{\circ} \mathrm{S}\right.$ ) (De Léo and Pires-Vanin, 2006).

Sampling was carried out in six stations $(5,10,15,25,35$, and $45 \mathrm{~m}$ depth) parallel to the coast line (Figure 1). The shallowest stations were categorized in this study as the "Inner Area" (5,10 and 15m depth), whereas the deepest ones were categorized as "Outer Area" (25, 35 and 45m depth). A shrimp fishing boat equipped with an otter-trawl net with an opening of $4.5 \mathrm{~m}, 200 \mathrm{~mm}$ mesh size and $15 \mathrm{~mm}$ in the cod end was used. The stations were trawled over a 15 minutes period at a constant speed of 2.0 knot through a $1 \mathrm{~km}$ stretch. In the laboratory, shrimp were identified following Pérez Farfante and Kensley (1997) and Costa et al. (2003).The total wet weight (in grams) was obtained for each species in each trawl. A $300 \mathrm{~g}$ sub-sample was randomly selected and all the individuals were counted and examined according to sex and length. Thus, based on the subsample and the total biomass, the estimate of the total number of individuals of each species in each station was determined. When the catch did not exceed $300 \mathrm{~g}$, all shrimps were measured (lowest sample size was 01 individual).

Salinity and temperature $\left({ }^{\circ} \mathrm{C}\right)$ were measured monthly in the surface and near the bottom in each station using a Van Dorn bottle. In the laboratory, salinity was verified 


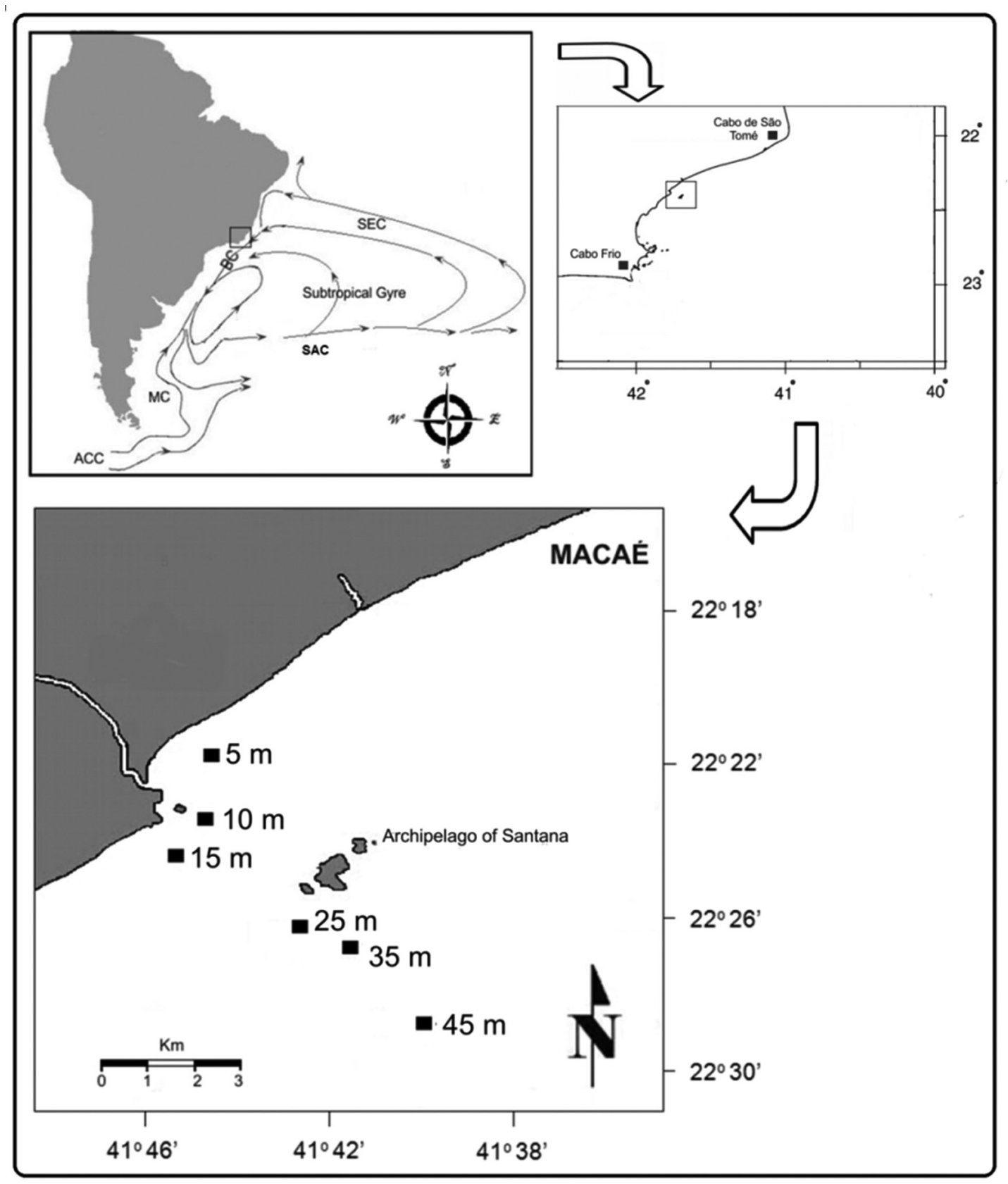

Figure 1. Study area evidencing the upwelling region and the sampling area. Location of stations (5-45 $\mathrm{m}$ of depth) and major ocean currents of the South Atlantic. ACC: Antarctic Circumpolar Current, MC: Malvinas Current, SAC: South Atlantic Current, SEC: South Equatorial Current, BC: Brazilian Current (Modified from Peterson and Stramma, 1991).

with a manual salinometer calibrated with distilled water. Water temperature was verified with a mercury thermometer immediately after sampling in a thermic isolated container in the shade. Depth was determined using an echobathymeter coupled with a Global Positioning System (GPS). Sediment samples were also collected in each season of the year in all sampling station using a Van Veen grab $\left(0.06 \mathrm{~m}^{2}\right)$. Details of the methods used to measure those parameters are described by Negreiros-Fransozo et al. (1991).
The periods under upwelling influence were identified through the Temperature-Salinity diagram (T-S) and by monthly difference between the highest surface temperature and the lowest bottom temperature.

Shrimp abundance (dependent variable) was compared temporally between years (years I: March 2008 to February 2009; year II: March 2009 to February 2010) and seasons (independent variables): autumn (March-May), winter (June-August), spring (September-November) and summer 
(December-February) using an analysis of variance (nested ANOVA) ( $\alpha$ 5\%) model, with seasons nested within years; it was also compared spatially between the station(independent variables) using an analysis of variance (one-way ANOVA) ( $\alpha$ 5\%) model. A post-hoc Tukey test was used to assess differences between stations.Normality of the data was examined by Levene's test.

The relationship between abiotic factors (salinity, temperature, phi and organic matter content) and the abundance of individuals was assessed with Multiple Linear Regression analysis at the 5\% significance level. For selecting the best model to represent the abundance of individuals in relation to the abiotic variables were generated models with all combinations of environmental variables that the number of shrimp is a constant. These models were compared using the Akaike Information Criterion (AIC). The best model was the one with the lowest AIC, which combines increased verisimilitude and parsimony (Sakamoto et al, 1986). According to Burnham and Anderson (2004), models with differences in AIC $<2$ do not
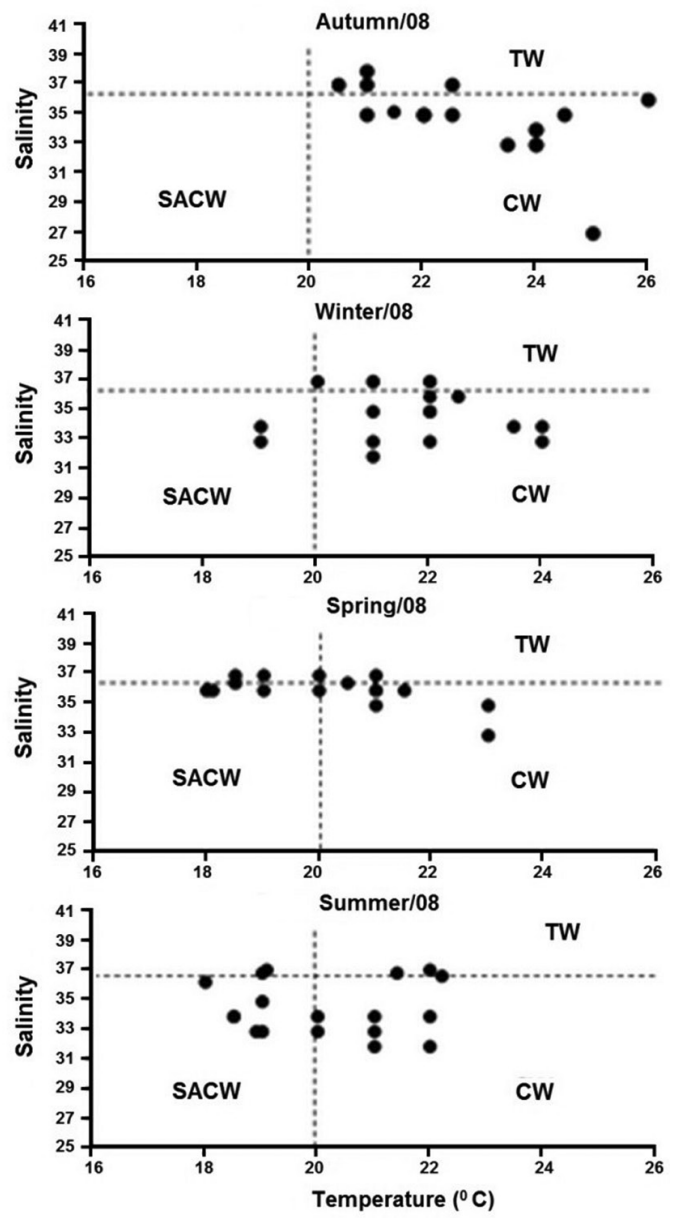

show a statistically significant difference. Analyzes were performed with R software (version 3.1.2) using Vegan package (Oksanen et al., 2011). The data were transformed by natural logarithm for the purpose of satisfying analytic premises (Zar, 1996).

\section{Results}

During the study period the water masses Coastal Water (CW), Tropical Water (TW) and South Atlantic Central Water (SACW) were identified. It was evident the influence of SACW during spring-summer months in both years, and in autumn (March-April) of the second year (Figure 2).

The smallest mean value of bottom salinity was recorded

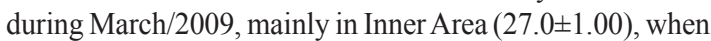
it was compared to Outer Area (31.7 \pm 3.21$)$. Contrarily, the greater values were verified in December/2008 (38.8 \pm 0.12$)$ and October/2009 (37.0 \pm 1.00$)$ in Inner Area, and April/2009 and Mach/2008 (37.7 \pm 0.58 e $37.3 \pm 0.58)$ in Outer Area (Figure 3).
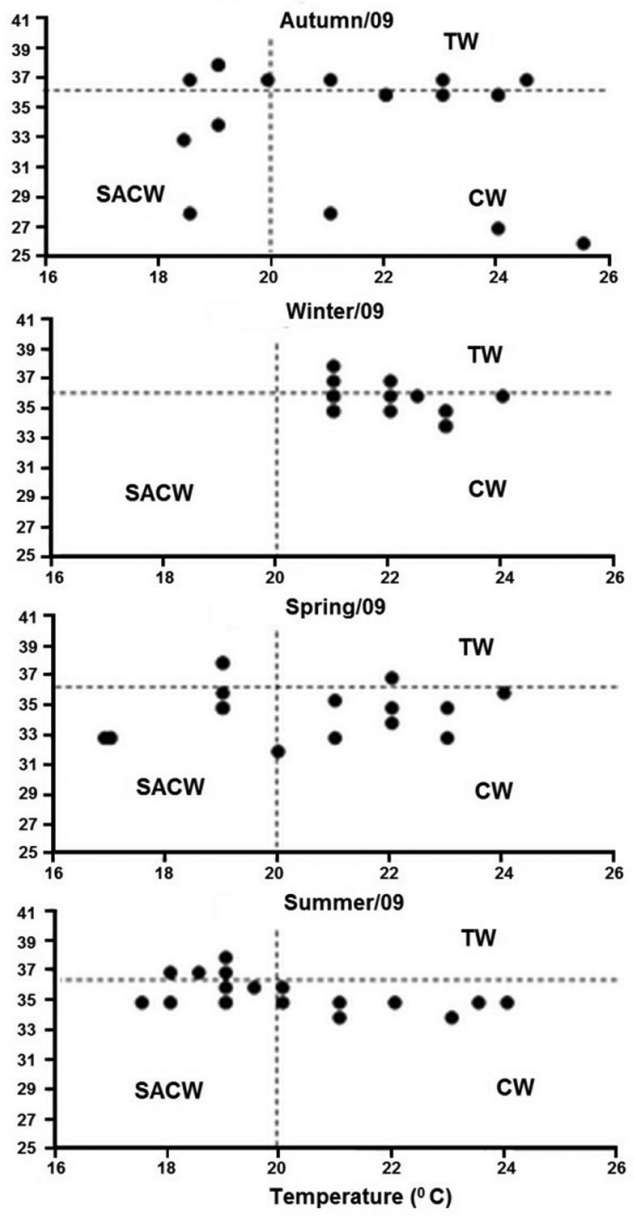

Figure 2. T-S Diagram showing the temporal variation of water temperature and salinity during the sampling period at upwelling area studied, Southeastern coast of Brazil. CW: Coastal Water; TW: Tropical Water; SACW: South Atlantic Central Water. (Autumn: March-May; Winter June-August; Spring September-November; and Summer means December-February). 
The smaller mean values of bottom temperature were observed in spring and summer of both years, mainly in January/2010 and November/2009 in Inner and Outer Area, respectively. The opposite was observed in winter with greater mean bottom temperature values (Figure 4).

The sediment in the Inner Area was composed mainly of medium sand and fine sand (phi varied from $1.23( \pm 0.5)$ to $2.79( \pm 1.6))$, and a low percentage of organic matter. In Outer Area the sediment was composed mainly of silt and clay (mean values above 5.49) and a greater content of organic matter (Figure 5).

A total of 7146 individuals were collected during the present study. About $96 \%$ of all shrimps were caught in the shallow area, i.e., depths $<20 \mathrm{~m}$ (Figure 6). The highest shrimp abundances occurred during winter and spring. Conversely, lowest abundance occurred during summer and autumn, particularly during summer 2009. The analysis of variance (nested ANOVA) indicates no significant

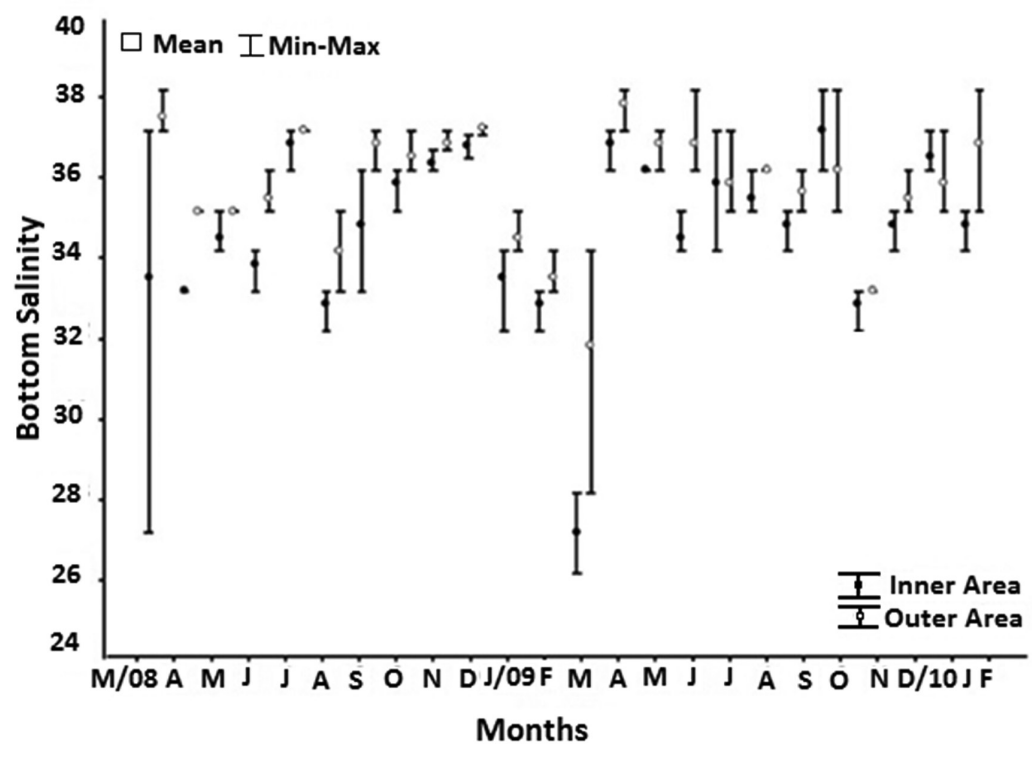

Figure 3. Average, maximum and minimum salinity values for each month in "Inner Area" (5, 10 and 15 m) and "Outer Area" (25, 35 and 45 m), sampled from March 2008 to February 2010.

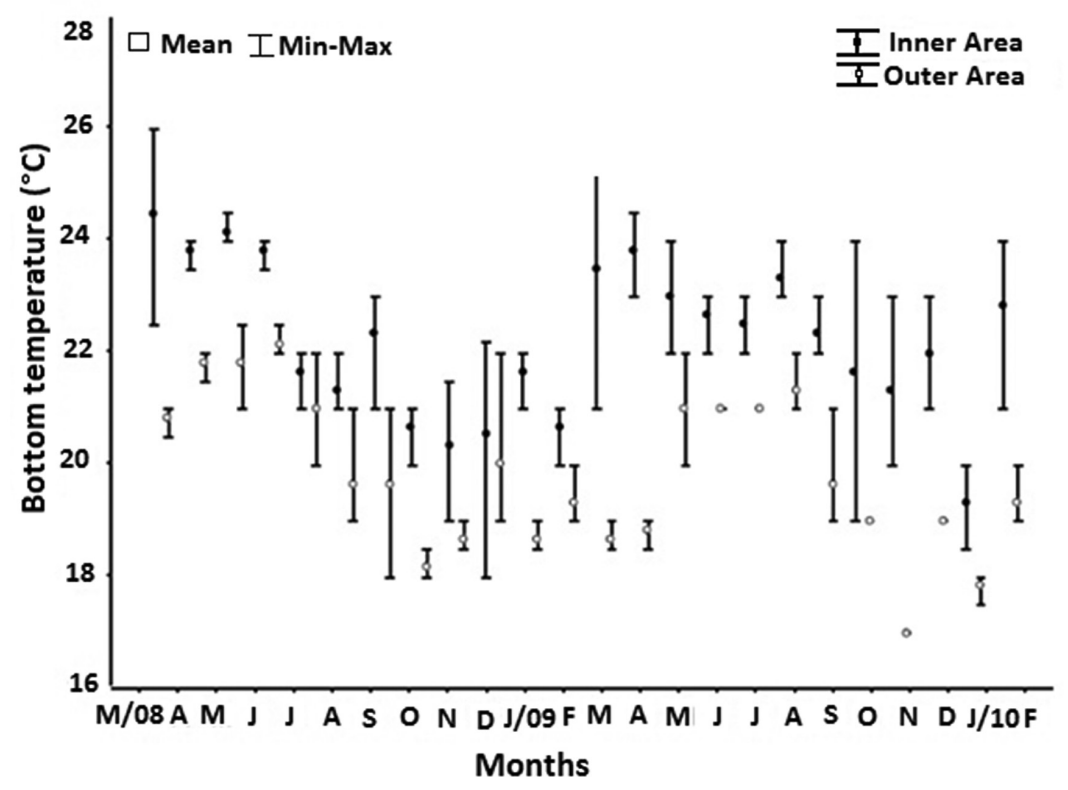

Figure 4. Average, maximum and minimum temperature $\left({ }^{\circ} \mathrm{C}\right)$ values for each month in "Inner Area" $(5,10$ and $15 \mathrm{~m})$ and "Outer Area" (25, 35 and 45 m) sampled from March 2008 to February 2010. 


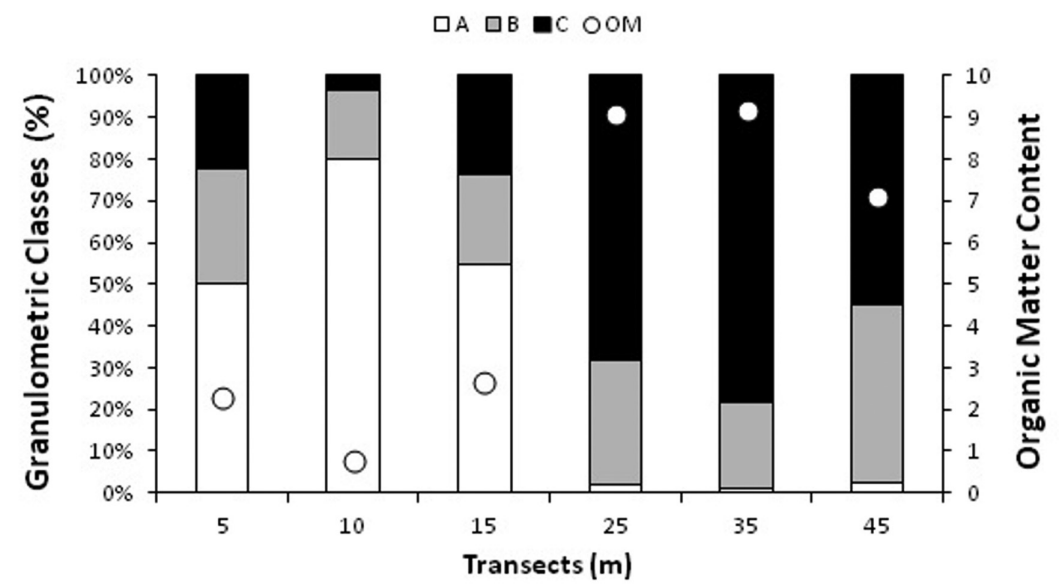

Figure 5. Granulometric Classes (\%) and Organic Matter Content of the sediment for each transect sampled from March 2008 to February 2010.

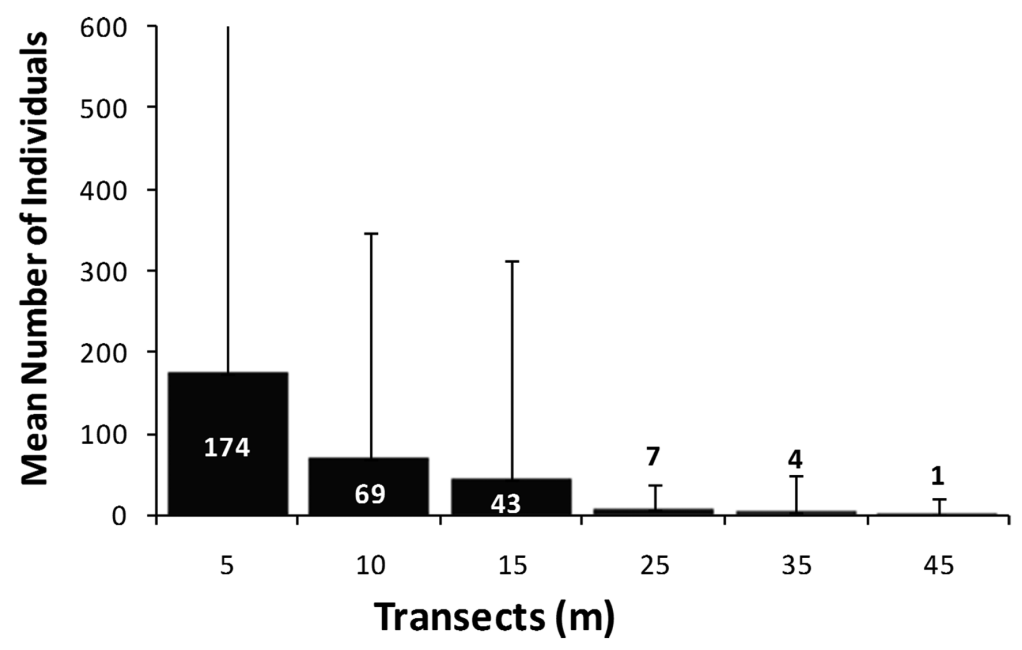

Figure 6. Average, maximum and minimum number of individual for each station sampled from March 2008 to February 2010.

difference in temporal comparison abundance between seasons $(\mathrm{F}=0.96 ; p=0.45)$ but it was marginally significant between years $(\mathrm{F}=3.32 ; p=0.07)$. The analysis of variance (one-way ANOVA) indicates significant difference in spatial comparison abundance between stations $(\mathrm{F}=35.0$; $p=0.00$ ) (Table 1).

The multiple regression analysis performed using the selected environmental variables (salinity, temperature, organic matter content and phi) and the abundance of Xiphopenaeus kroyeri $\left(\mathrm{r}^{2}=0.4, p<0.001, \mathrm{~F}=1.2 \mathrm{E}-15\right.$, $n=144$ ) can be expressed by the following relationship: $\mathrm{A}=-15.4+7.1 \mathrm{t}+4.8 \mathrm{~s}-1.4 \mathrm{om}$; where: $\mathrm{A}=$ abundance; $\mathrm{t}=$ bottom temperature (partial correlation $=4.6, \mathrm{r}^{2}=0.2$, $p<0.001$ ); $\mathrm{s}=$ bottom salinity (partial correlation $=2.3$, $\left.\mathrm{r}^{2}=0.02, p<0.05\right), \mathrm{om}=$ organic matter content (partial correlation $\left.=-2.5, \mathrm{r}^{2}=0.3, p<0.05\right)$. The abiotic factors temperature and salinity were positively correlated with the number of collected individuals, nonetheless organic matter content was negative correlation. No significant relationship was observed between sediment (phi) and abundance $(p>0.05)$. The variable depth was not included in this analysis, considering that abiotic variables temperature and salinity are heavily related to the depth, the use of this variable trend analysis results.

\section{Discussion}

The distribution of $X$. kroyeri in the study area is intimately associated with the seasonality of the thermal front of SACW. This close association was also observed by Pires-Vanin et al. (2013), on the north coast of São Paulo, where the seasonality of SACW affected macrofauna benthic invertebrates distribution patterns. Furthermore, Dall et al. (1990) and Costa and Fransozo (2004) stated that temperature is a major determinant parameter in the temporal distribution of organisms, especially for penaeid shrimp. 


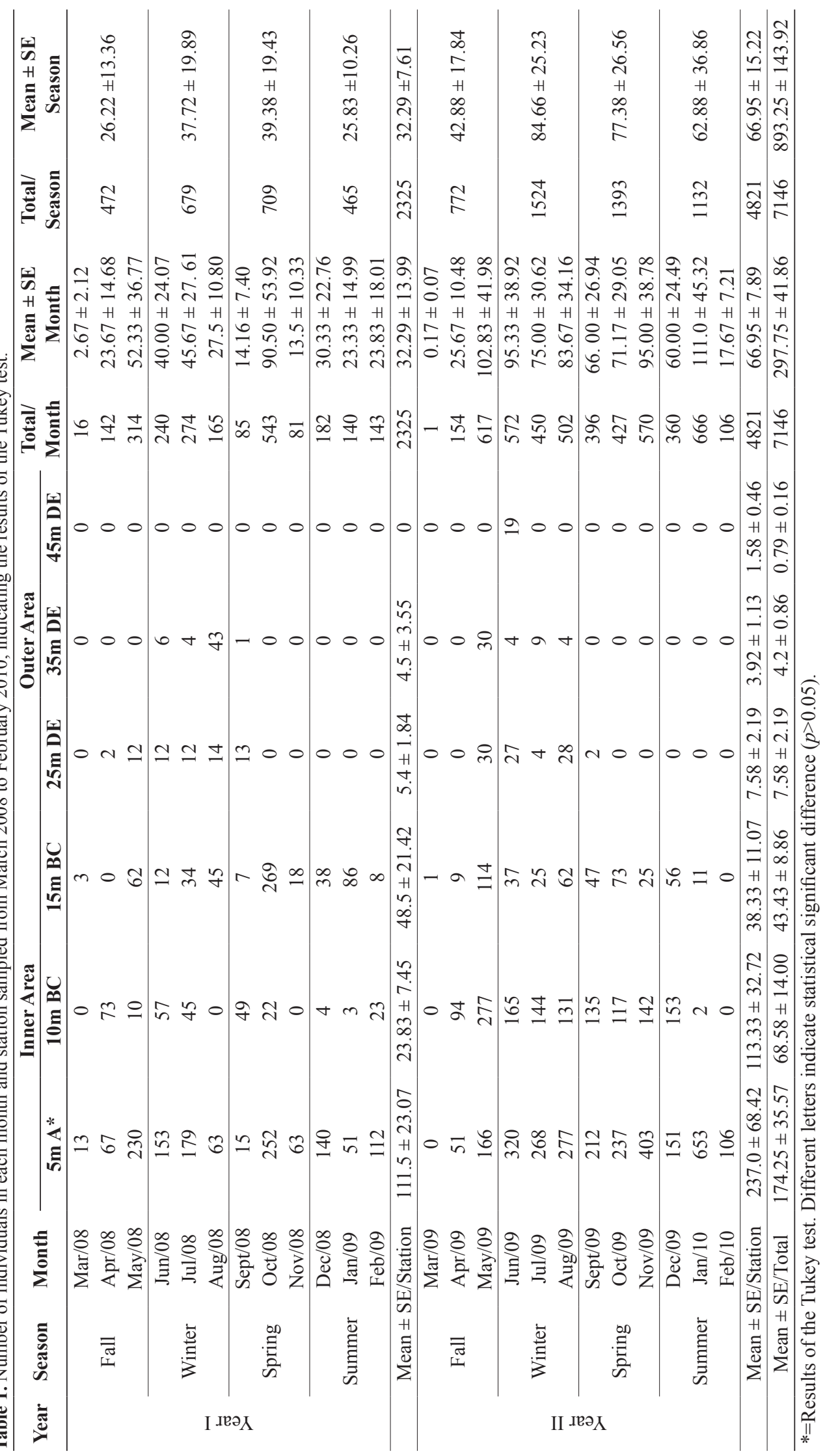


The intrusion of SACW in the spring and summer which promoted decrease in the values of bottom temperature especially in deeper areas, allowing individuals to occupy shallower areas, where temperatures remained higher average $\left(>22{ }^{\circ} \mathrm{C}\right)$. In contrast, the absence of this water mass during the fall and winter provided a rise in the bottom water temperature and consequently an increase in the abundance of $X$. kroyeri, especially in transects positioned in deeper areas. In the study by Nakagaki and Negreiros-Fransozo (1998) was also observed variations in the abundance of this species due to greater penetration of SACW in regions closer to the coast. Similar results were observed by Fransozo et al. (2002) and Costa et al. (2007) for X. kroyeri, everyone conducted in Ubatuba, northern coast of São Paulo state.

Several authors have suggested that penaeoid shrimp distribution is strongly modulated by the texture and organic content of the substrate (Rulifson, 1981; Dall et al., 1990; Sanchez, 1997; Costa et al. 2007). Our results contradict these assertions since no correlation was found between $X$. kroyeri and texture of the sediment, and a negative correlation was observed between their abundance and organic matter content of the substrate. A possible hypothesis is that this result is a reflection of the high catch of $X$. kroyeri in the shallower areas where the organic matter content is low; this shrimp species occurs at temperatures above $21^{\circ} \mathrm{C}$ (Costa et al., 2007) and in the present study area, stations with predominantly muddy sediments showed lower temperature than $21^{\circ} \mathrm{C}$. This leads to assume that the temperature in these areas is the primary factor in the establishment of individuals of this species.

The sediment in shallow areas was predominantly medium and fine sand and, conversely, the outer area was characterized by sediment composed of silt and clay. Garcêz (2007) explained this by the formation of a tombolo submarine (submerged sandy track) between the beach and the Archipelago de Santana included in the study area. This sandy strip provides in shallow areas a removal of fine sediments by wave action, establishing an irregular facies pattern of medium and very coarse sand. The muddy sediments occur preferentially above 15 meters depht. This result also supports the conclusion that the species has a great plasticity in relation to sediment type. Other studies such as those developed in Ubatuba, São Paulo State (Freire et al., 2011; Costa et al., 2007) found that this species prefers muddy sediments, which in this study area occurred in shallower portions.

According to the study results, the temperature is the main factor modeler of abundance and spatial-temporal distribution of $X$. Kroyeri, being controlled by the variations in temperature caused by the SACW intrusion in the region. Thus, in periods that occurs most influences of the cold waters of SACW in the coast of Macaé, shrimps migrate to shallower depths where the temperature remains higher means. Likewise, the abundance of $X$. kroyeri suffer temporal variations, being modulated by the higher or lower SACW influence.

\section{Acknowledgments}

The authors are grateful to the "Financiadora de Estudos e Projetos (Finep/Ministério de Ciência e Tecnologia) for the financial support to the field work; to the "Conselho Nacional de Desenvolvimento Científico e Tecnológico (CNPq) (APQ - 305919/2014-8 and APQ - 406006/2012-1RCC)", to the "Fundação de Amparo à Pesquisa do Estado do Rio de Janeiro (FAPERJ)", and to the "Fundação de Amparo à Pesquisa do Estado de São Paulo (FAPESP) (\#09/54672-4 and 010/50188-8-RCC)" for funding; and also to the "Coordenação de Aperfeiçoamento de Pessoal de Nível Superior (CAPES)" for the fellwoship to the first author. We also thank to the "Universidade Federal do Rio de Janeiro (NUPEM/UFRJ)" for the infrastructure provided for the execution of this project and our collaborators (NEBECC and LABCAM members) for field and laboratory assistance. All samplings were carried out in accordance with Brazilian state and federal laws (Instituto Chico Mendes de Biodiversidade/ICMBio ${ }^{\circ}$ 11274).

\section{References}

ACHA, E.M., MIANZAN, H.W., GUERRERO, R.A., FAVERO, M. and BAVA, J., 2004. Marine fronts at the continental shelves of austral South America physical and ecological processes. Journal of Marine Systems, vol. 44, no. 1-2, pp. 83-105. http:// dx.doi.org/10.1016/j.jmarsys.2003.09.005

ALMEIDA, A.C., BAEZA, J.A., FRANSOZO, V., CASTILHO, A.L. and FRANSOZO, A., 2012a. Reproductive biology and recruitment of Xiphopenaeus kroyeri in a marine protected area in the Western Atlantic: implications for resource management. Aquatic Biology, vol. 17, no. 1, pp. 57-69. http://dx.doi.org/10.3354/ ab00462.

ALMEIDA, A.C., FRANSOZO, A., TEIXEIRA, G.M., HIROKI, K.A.N., FURLAN, M. and BERTINI, G., 2012b. Ecological distribution of the shrimp Nematopalaemon schmitti (Crustacea: Decapoda: Caridea) in three bays on the south-eastern coast of Brazil. African Journal of Marine Science, vol. 34, no. 1, pp. 93102. http://dx.doi.org/10.2989/1814232X.2012.673292.

BOHNSACK, J.A., 1998. Marine reserves, zoning and the future of fisheries management. Fisheries (Bethesda, Md.), vol. 21, no. 9, pp. 14-16.

BOSCHI, E.E., 1963. Los camaronês comerciales de la família Penaeidae de lacosta Atlántica de América delSur. Boletim do Instituto de Biologia Marinha, vol. 3, pp. 1-39.

BRANCO, J.O., 2005. Biologia e pesca do camarão sete-barbas Xiphopenaeus kroyeri (Heller) (Crustacea, Penaeidae), na Armação do Itapocoroy, Penha, Santa Catarina, Brasil. Revista Brasileira de Zoologia, vol. 22, no. 4, pp. 1050-1062. http://dx.doi.org/10.1590/ S0101-81752005000400034.

BRASIL. Ministério do Meio Ambiente-MMA, 2004. Instrução Normativa $n^{\circ}$ 5, de 21 de maio de 2004. Dispõe sobre espécies ameaçadas de extinção e espécies sobreexploradas ou ameaçadas de sobreexploração, os invertebrados aquáticos e peixes. Diário Oficial da União, Brasília, 28 maio.

BRASIL. Ministério do Meio Ambiente-MMA, 2007. Áreas aquáticas protegidas como instrumento de gestão pesqueira. 
Brasília: Ministério do Meio Ambiente. pp. 4-13. Série Áreas Protegidas do Brasil, 4.

BURNHAM, K.P. and ANDERSON, D.R., 2004. Multimo delinference: Understanding AIC e BIC in model. Sociological Methods Reseach, vol. 33, no. 2, pp. 261-304.

CAMPOS, E.J.D., IKEDA, Y., CASTRO, B.M., GAETA, S.A., LORENZZETTI, J.A. and STEVENSON, M.R., 1996. Experiment studies circulation in the western South Atlantic. Eos, Transactions, American Geophysical Union, vol. 77, no. 27, pp. 253-259. http:// dx.doi.org/10.1029/96EO00177.

CAMPOS, E.J.D., VELHOTE, D. and DA SILVEIRA, I.C.A., 2000. Shelf break upwelling driven by Brazil Current cyclonic meanders. Geophysical Research Letters, vol. 27, no. 6, pp. 751754. http://dx.doi.org/10.1029/1999GL010502.

CASTRO, B.M. and MIRANDA, L.B., 1998. Physical oceanography of the western Atlantic continental shelf located between $4^{\circ} \mathrm{N}$ and $34^{\circ}$ S. In: A.R. ROBINSON, K.H. BRINK, eds. The sea. New York: Wiley. pp. 209-251.

CASTRO, R.H., COSTA, R.C., FRANSOZO, A. and MANTELATTO, F.L.M., 2005. Population structure of seabob shrimp Xiphopenaeus kroyeri (Heller, 1862) (Crustacea: Penaeoidea) in the littoral of São Paulo, Brazil. Scientia Marina, vol. 69, pp. 105-112.

CASTRO-FILHO, B.M., MIRANDA, L.B. and MIYAO, S.Y., 1987. Condições hidrográficas na plataforma continental ao largo de Ubatuba: variações sazonais e em média escala. Boletim do Instituto Oceanográfico da Universidade de São Paulo, vol. 35, no. 2, pp. 135-151.

COSTA, R.C. and FRANSOZO, A., 2004. Abundance and ecologic distribution of the shrimp Rimapenaeus constrictus (Crustacea: Penaeidae) in the northern coast of São Paulo State, Brazil. Journal of Natural History, vol. 38, no. 7, pp. 901-912. http://dx.doi.org/10.1080/0022293021000046441.

COSTA, R.C., FRANSOZO, A., CASTILHO, A.L. and FREIRE, F.A.M., 2005. Annual, seasonal and spatial variation of abundance of Artemesia longinaris (Decapoda, Penaeoidea) in a region a southeastern region of Brazil. Journal of the Marine Biological Association of the United Kingdom, vol. 85, no. 1, pp. 107-112. http://dx.doi.org/10.1017/S0025315405010908h.

COSTA, R.C., FRANSOZO, A., FREIRE, F.A.M. and CASTILHO, A.L., 2007. Abundance and ecological distribution of the "setebarbas" shrimp Xipohpenaeuskroyeri(Heller, 1862) (Decapoda: Penaeoidea) in three bays of the Ubatuba region, South-eastern Brazil. Gulf and Caribbean Research, vol. 19, pp. 33-41.

COSTA, R.C., FRANSOZO, A., MELO, G.A.S. and FREIRE, F.A.M., 2003. An illustrated key for Dendrobranchiata shrimps from the northern coast of São Paulo state, Brazil. Biota Neotropica, vol. 3 , no. 1 , pp. 1-12.

COSTA, R.C., HECKLER, G.S., SIMÕES, S.M., LOPES, M. and CASTILHO, A.L., 2011. Seasonal variation and environmental influences on abundance of juveniles of the seabob shrimp Xiphopenaeus kroyeri (Heller, 1862) in southeastern Brazil. In: D. PESSANI, C. FROGLIA, E. BIAGGI, N. NURRA, R. BASILI, S. BONELLI, E. GAVETTI, R.M. SARTOR, G. RAPPINI, T. TIRELLI, eds. Behaviour, ecology, fishery. Turin: Museo Regionale di Scienze Naturali di Torino, pp. 45-56.

D'INCAO, F., VALENTINI, H. and RODRIGUES, L.F., 2002. Avaliação da pesca de camarões nas regiões sudeste e sul do Brasil: 1965-1999. Atlantica, vol. 24, pp. 103-116.
DALL, W., HILL, B.J., ROTHLISBERG, P.C. and SHARPLES, D.J., 1990. The biology of the Penaeidae. Advances in Marine Biology, vol. 27, pp. 1-489.

DAYTON, P.K., SALA, E., TEGNER, M.J. and THRUSH, S., 2000. Marine reserves: parks, baselines and fishery enhancement. Bulletin of Marine Science, vol. 66, no. 3, pp. 617-634

DE LEO, F.C. and PIRES-VANIN, A.M.S., 2006. Benthic megafauna communities under the influence of the South Atlantic Central Water intrusion onto the Brazilian SE shelf: a comparison between an upwelling and a non-upwelling ecosystem. Journal of Marine Systems, vol. 60, no. 3-4, pp. 268-284. http://dx.doi. org/10.1016/j.jmarsys.2006.02.002.

DUDLEY, N., 2008. Guidelines for applying protected area management categories. Gland: IUCN. 86 p.

FERREIRA, B.P. and MAIDA, M., 2001. Fishing and the future of Brazil's Northeastern reefs. Integrated Coastal Zone and ShelfSea Research, vol. 38, pp. 22-23.

FRANSOZO, A., COSTA, R.C., MANTELATTO, F.L.M., PINHEIRO, M.A.A. and SANTOS, S., 2002. Composition and abundance of shrimp species (Peneidea and Caridea) in Fortaleza bay, Ubatuba, São Paulo, Brazil. In: E. ESCOBAR-BRIONES and F. ALVAREZ, eds. Modern approaches to the study of crustacea. Dordrecht: Kluwer Academic Publishers, pp. 117-125.

FREIRE, F.A.M., LUCHIARI, A.C. and FRANSOZO, V., 2011. Environmental substrate selection and daily habitual activity in Xiphopeneus kroyeri shrimp (Heller, 1862) (Crustacea: Penaeioidea). Indian Journal of Geo-marine Science, vol. 40, no. 3, pp. 325-330.

GARCÊZ, D.S., 2007. Caracterização da pesca artesanal autônoma em distintos compartimentos fisiográficos e suas áreas de influência, no estado do Rio de Janeiro. Rio de Janeiro: Universidade Federal do Rio de Janeiro, 125 p. PhD Thesis in Geography.

GELL, F.R. and ROBERTS, C.M., 2003. Benefits beyond boundaries: the fishery effects of marine reserves. Trends in Ecology \& Evolution, vol. 18, no. 9, pp. 448-455. http://dx.doi. org/10.1016/S0169-5347(03)00189-7.

GILLETT, R., 2008. Global study of shrimp fisheries. Rome: FAO, 475 p. Fisheries Technical Paper.

HALPERN, B.S. and WARNER, R.R., 2002. Marine reserves have rapid and lasting effects. Ecology Letters, vol. 5, no. 3, pp. 361-366. http://dx.doi.org/10.1046/j.1461-0248.2002.00326.x.

HECKLER, G.S., SIMÕES, S.M., SANTOS, A.P.F., FRANSOZO, A. and COSTA, R.C., 2013. Population dynamics of the seabob shrimp Xiphopenaeus kroyeri (Dendrobranchiata, Penaeidae) in south-eastern Brazil. African Journal of Marine Science, vol. 35, no. 1, pp. 17-24. http://dx.doi.org/10.2989/1814232X.2013.769901.

HOLTHUIS, L.B., 1980. Shrimps and prawns of the world: An annotated catalogue of species of interest to fisheries. Rome: FAO, 125 p. Fisheries Synopsis.

HYRENBACH, K.D., FORNEY, K.A. and DAYTON, P.K., 2000. Marine protected areas and ocean basin management. Aquatic Conservation: marine and freshwater ecosystems, vol. 10 , pp. $437-458$

INSTITUTO BRASILEIRO DO MEIO AMBIENTE E DOS RECURSOS NATURAIS RENOVÁVEIS - IBAMA. Centro Nacional de Pesquisa e Conservação da Biodiversidade Marinha do Sudeste e Sul-CEPSUL, 2006. Relatório da reunião técnica de análise da pescaria do camarão sete-barbas (Xiphopenaeus kroyeri). Itajaí: Ministério do Meio Ambiente. 
LUBCHENCO, J., PALUMBI, S.R., GAINES, S.D. and ANDELMAN, S., 2003. Plugging the hole in the ocean: the emerging science of marine reserves. Ecological Application, vol. 13, no. 1, suppl, pp. S3-S7.

NAKAGAKI, J.M. and NEGREIROS-FRANSOZO, M.L., 1998. Population biology of Xiphopenaeus kroyeri (Heller, 1862) (Decapoda: Penaeidae) from Ubatuba bay, São Paulo, Brazil. Journal of Shellfish Research, vol. 17, no. 4, pp. 931-935.

NEGREIROS-FRANSOZO, M.L., FRANSOZO, A., PINHEIRO, M.A.A., MANTELATTO, F.L. and SANTOS, S., 1991. Caracterização física e química da enseada da Fortaleza, Ubatuba, SP. Revista Brasileira de Geografia, vol. 21, no. 2, pp. 114-120.

OKSANEN, J., BLANCHETT, F.G., KINDT, R., LEGENDRE, P., MINCHIN, P.R., O'HARA, R.B., SIMPSON, G.L., SOLYMOS, P., STEVENS, M.H.M. and WAGNER, H. 2011. Vegan: community Ecology Package. R Package 2.0.3 [software]. R-Forge.

PÉREZ-FARFANTE, I. and KENSLEY, B., 1997. Penaeoid and Segestoid shrimps and prawns of the World. Keys and diagnosese for the families and genera. Paris: Museum National d'Histoire Naturelle, 233 p. Memoires du Museum National d'Histoire Naturel.

PETERSON, R. and STRAMMA, L., 1991. Upper-level circulation in the South Atlantic Ocean. Progress in Oceanography, vol. 26, no. 1, pp. 1-73.

PIRES VANIN, A.M.S., ARASAKI, E. and MUNIZ, P., 2013. Spatial pattern of benthic macrofauna in a sub-tropical shelf, São Sebastião Channel, southeastern Brazil. Latin American Journal of Aquatic Research, vol. 41, no. 1, pp. 42-56. http://dx.doi. org/10.3856/vol41-issue1-fulltext-3.

RULIFSON, R.A., 1981. Substrate preference of juvenile penaeid shrimp in estuarine habitats. Contributions in Marine Science, vol. 24 , pp. 33-52.

RUSS, G.R. and ALCALA, A.C., 2011. Enhanced biodiversity beyond marine reserves boundaries: the cup spillith over. Ecological Applications, vol. 21, no. 1, pp. 241-250. http://dx.doi. org/10.1890/09-1197.1. PMid:21516901.

SAKAMOTO, Y., ISHIGURO, M. and KITAGAWA, G., 1986. Akaike information criterion statistics. Tokio: KTK Scientific Publisher/D. Riedel, 290 p.

SÁNCHEZ, A.J., 1997. Habitat preference of Penaeus duorarum Burkenroad (Crustacea: Decapoda) in a tropical coastal lagoon, southwest Gulf of Mexico. Journal of Experimental Marine Biology and Ecology, vol. 217, no. 1, pp. 107-117. http://dx.doi. org/10.1016/S0022-0981(97)00049-X.
SANCINETTI, G.S., AZEVEDO, A., CASTILHO, A.L., FRANSOZO, A. and COSTA, R.C., 2014. How marine upwelling influences the distribution of Artemesia longinaris (Decapoda: Penaeoidea)? Latin American Journal of Aquatic Research, vol. 42, no. 2, pp. 322-331.

SANCINETTI, G.S., AZEVEDO, A., CASTILHO, A.L., FRANSOZO, A. and COSTA, R.C., 2015. Population biology of the commercially exploited shrimp Artemesia longinaris (Decapoda: Penaeidae) in an upwelling region in the Western Atlantic: comparisons at different latitudes. Brazilian Journal of Biology $=$ Revista Brasileira de Biologia, vol. 75, no. 2, pp. 305313. http://dx.doi.org/10.1590/1519-6984.11813. PMid:26132012.

SEMENSATO, X.E.G. and DI BENEDITTO, A.P.M., 2008. Population dynamic and reproduction of Artemesia longinaris (Decapoda, Penaeidae) in Rio de Janeiro State, South-eastern Brazil. Boletim do Instituto de Pesca, vol. 34, pp. 89-98.

SILVA, E.R., 2013. Dinâmica Populacional do Camarão Sete-Barbas Xiphopenaeus kroyeri (Heller, 1862) (Decapoda: Penaeoidea) no Litoral de Macaé-RJ. Macaé: Universidade Federal do Rio de Janeiro, 112 p. Masters Dissertation in Biology.

SILVEIRA, I.C.A., SCHMIDT, A.C.K., CAMPOS, E.J.D., GODOI. S.S. and IKEDA, Y., 2000. A Corrente do Brasil ao largo da costa leste brasileira. Boletim do Instituto Paulista de Oceanografia, vol. 48 , no. 2 , pp. 171-183.

VALENTIN, J.L., 1984. Analyses des parameters hydrobiologiques danslaremontée de Cabo Frio (Brésil). Marine Biology, vol. 82, pp. 259-276.

VALENTINI, H. and D'INCAO, F., RODRIGUES, L.F., REBELONETO, J.E. and RAHN, E., 1991b. Análise da pesca do camarão-rosa (Penaeus brasiliensis e P. paulensis) nas regiões sudeste e sul do Brasil. Atlântica, vol. 13, no. 1, pp. 143-158.

VALENTINI, H., D’INCAO, F., RODRIGUES, L.F., REBELONETO, J.E. and DOMIT, L.G., 1991a. Análise da pesca do camarãosetebarbas (Xiphopenaeus kroyeri) nas regiões sudeste e sul do Brasil. Atlantica, vol. 13, no. 1, pp. 171-178.

VASCONCELlOS, M., DIEGUES, A.C. and SALLES, R.R., 2007. Limites e gestão da pesca artesanal costeira. In: A.L. COSTA, ed. Nas redes da pesca artesanal. Brasília: PNUD/ IBAMA, pp. 15-83.

ZAR, J.H., 1996. Biostatistical analysis. Upper Saddle River: Prentice Hall. 662 p. 